\title{
Bio-inspired Back Support System for Backpacks
}

Elena Angeleska

Assistant

University of Cyril and Methodius Faculty of Mechanical Engineering Republic of North Macedonia

Sofija Sidorenko

Full Professor

University of Cyril and Methodius Faculty of Mechanical Engineering Republic of North Macedonia

In this paper a solution-driven bionic approach applied in a process of product redesign with intention to improve its ergonomic properties is presented. The main goal was to reformulate and use the properties of a unique natural phenomenon in a specific design field.

The skeletal structure of the seahorse, its load-bearing capacity with retained flexibility, was an inspiration to explore products where these properties could be applied for improving the functionality. The research process resulted with detecting a problem caused by poor product design spine deformities of students caused by non-ergonomic school backpacks. This ignited the idea to use the analyzed biological properties for designing school backpacks with improved ergonomics. The final result was the design of school backpacks with an integrated mechanical system based on the biological skeletal structure of the seahorse which would help to achieve maximum comfort and support the healthy posture of students.

Keywords: Bionics, Ergonomics, Industrial design, Sea horse skeleton, School backpack

\section{INTRODUCTION}

The technological advances and design of new products are often directly inspired by nature, given the fact that in our everyday lives we encounter the same kind of problems as organisms in nature. Natural selection and changing environmental conditions have led organisms to respond to a wide range of problems with the creation of robust and efficient solutions. Through evolution, these solutions were tested according to their effects on the organism's efficiency and, afterwards, were kept or completely rejected. This process is, in many ways, similar to the design cycles. Therefore, it comes as no surprise that engineers and designers often turn towards nature to seek inspiration for creating novelties, viewing nature as a vast database of already tried and tested solutions to various problems. The roots of this methodology, known as bionics, bio-mimicry or biologically inspired design, date back from pre-historic times when humans learned to imitate nature in order to create survival tools. During the period of renaissance biomimicry is apparent in the designs of the visionary Leonardo da Vinci [1].

Today, researchers investigate methods for optimal application of bionic methodologies in modern design. The aim of these methods is to help engineers, designers and other professionals promote the creation of bio-mimicry products. Camila F. Salgueiredo from the University of Evry Val d'Essonne, focuses on the principles of $\mathrm{C}-\mathrm{K}$ theory (originally introduced by Hatchuel and Weil) where $\mathrm{C}$ is the space of Concepts and $\mathrm{K}$ is the space of Traditional Knowledge and Biological Knowledge. Examples are given of how the

Received: December 2020, Accepted: February 2021

Correspondence to: Elena Angeleska, University of

Cyril and Methodius, Faculty of Mechanical

Engineering, Skopje, Republic of North Macedonia

E-mail: elena.angeleska@mf.edu.mk

doi: 10.5937/fme2102327A

(C) Faculty of Mechanical Engineering, Belgrade. All rights reserved branching of a concept results with expansion in the $\mathrm{K}$ space. This is a way of searching for new knowledge in nature and finding sometimes unexpected properties that influence the traditional knowledge and the generation of concepts for products [2].

Furthermore, a couple of approaches are proposed to be used in the process of designing new products following natural shapes and principles. Helms, Vattam and Goel describe a 6-step process to organize the bionic research when an exact source of a design problem is pinpointed and possible solutions are needed [3]. They also discuss a reverse, solution-driven process. Similarly, Versos and Coelho elaborate a bi-directional method describing the design stages required to get from a problem to a solution and the other way around [4].

For example, aiming to solve the issue with liftinduced drag of transport aircrafts, Gavrilović, Rašuo, Dulikravich and Parezanović, investigate the wingtip formations of birds in order to implement their principles by bionic abstraction [5], which is an excellent example of a problem-induced bionic approach. On the other hand, in the paper titled "Development of a Miniature Robot Based on Experience Inspired by Nature", Stevanović and Rašuo use a solution-driven process. Inspired by the motion of legged biological organisms, they apply the studied principles in the design and movement of a miniature robot [6].

Universities from around the world have adopted and adapted these approaches in order to encourage students to come up with ways to convert their knowledge of natural phenomenons into technological solutions. Neurohr and Dragomirescuhe from the Polithenica University of Bucharest give a graphic representation of the "top-down" and "bottom-up" approaches for "integrating bionics into technological development" describing the field (Technology, Bionics or Biology) the steps of each approach belong in [7]. The Industrial Design students from the Faculty of Mechanical Engineering in Skopje use these approaches 
as well. After deciding upon a natural phenomenon to be applied in a new design or a problem to be solved, a structured way of reformulating of the natural solution or the design problem is used. The reformulation means using deduction that results with keywords that help to generate better concepts [8]. There are numerous examples of student's projects proving the success of this deductive approach $[9,10]$. Moreover, Emami, Tashakori and Tashakorinia from the Fine Arts Faculty, University of Tehran, Tehran, Iran, list 4 concerns as a starting point in the bionic research: "Natural and functional systems; Forms related to function; Creature behaviour and life style; and Environment and interactions" [11]. The first two points result with the creation of a form and function similar to a natural phenomenon and the second two promote the sustainable design movement.

This paper describes a solution-driven bionic approach. A unique natural phenomenon is identified and its properties are analysed in detail in order to reformulate them and search for specific design and engineering fields where they can be applied. The method of reformulation offers identification of a product that could be improved by direct application of the formand-function features of the natural phenomenon. The product is re-designed later using the biologically inspired methodology. The main goal of the paper is to share a fresh perspective for designing an everyday item with intention to improve its ergonomic features. By doing so, the importance of bionics, as an approach that results with products that solve existing problems and meet specific functional requirements, is emphasised. The need for using this method for educational purposes is stated, as well. The benefits of the elaborated approach in the teaching process are numerous: helping systematize ideas, expanding knowledge and triggering creative thinking among design and engineering students in new product development.

This paper is based on a bottom-up approach where a natural solution is identified, reformulated and based on the defined functional properties a possible problem that can be solved is searched for. After identifying a potential problem by focusing on concerns related with form and function, concepts are generated and elaborated.

\section{IDENTIFICATION OF A NATURAL PHENOMENON}

\subsection{Description of the natural phenomenon - functional properties}

The seahorse as a natural organism has been in the centre of many biological and engineering researches due to multiple specific reasons. One of its key characteristics is the function of its skeleton that at the same time serves as an external protective armour, but it is also extremely moveable and flexible. Tomas Praet from the Faculty of Engineering and Architecture, Ghent University, Belgium, gives an in-depth analysis of the seahorse tail anatomy and how it can serve as an inspiration in design, engineering and robotics [12]. The skeleton of the tail consists of a chain of bony segments each containing a central vertebra and 4 dermal Lshaped plates connected to it (Fig. 1). All these parts are connected with special joints that can bend and twist and support weight and hits without breaking. Through a chain reaction between all these segments, the tail of a seahorse can rotate up to $360^{\circ}$. This type of flexibility of the skeleton allows the seahorse to move and fixate to underwater objects. In addition, the skeleton protects them from predators since the tail can be compressed up to $50 \%$ of its original width before any serious damage is done to it. This happens due to an even distribution of forces no matter what angle they are coming from.

\subsection{Structure of the natural phenomenon}

All of the mentioned properties of the tail of the seahorse are possible because of the specific formation of all its elements and the way they are connected with each other. The tail of a seahorse consists of a chain of about 30 skeletal segments that gradually decrease in size and increase their tilting toward the tip of the tail. Each of the segments is consisted of 5 parts: central vertebra, left dorsal dermal plate, right dorsal dermal plate, left ventral dermal plate and right ventral dermal plate. The vertebra has 4 tissue extensions that connect with the dermal plates by joints that allow 3 degrees of rotation forming a "peg-and-socket" type of connection. The joints between subsequent vertebra also allow rotation around 3 axes. The 4 dermal plates of a same segment are connected by gliding joints that appear like a ridge on one plate over which the other plate slides. Subsequent dermal plates are connected by a similar type of gliding joints. The plates have extensions towards the tail of the seahorse that fit into a cavity on following plate which is oriented towards the side of the seahorse head. As a summary, the different behaviour of all the joints of each segment makes the complex movements possible.

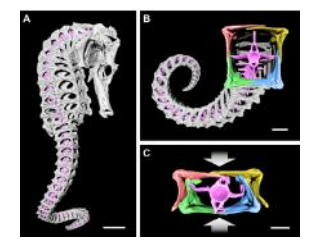

Figure 1. The skeleton of a seahorse (Source: Justin Holt, Design and Testing of a Biomimetic Pneumatic Actuated Seahorse Tail Inspired Robot [13])

\subsection{Reformulation of the identified natural phenomenon - functional decomposition}

After analysing the form and function of the seahorse skeleton and identifying its unique characteristics, the following step is a reformulation of the natural solution in order to highlight the properties that can be used to design a new product. The main properties are:

- Good distribution of forces

- Great durability under compression

- Shock absorption

- Lightweight structure

- Compact design

- Great flexibility and freedom of movement

Moreover, for a complete reformulation, a detailed functional decomposition was made which helps to understand how these properties are achieved (Fig. 2). 


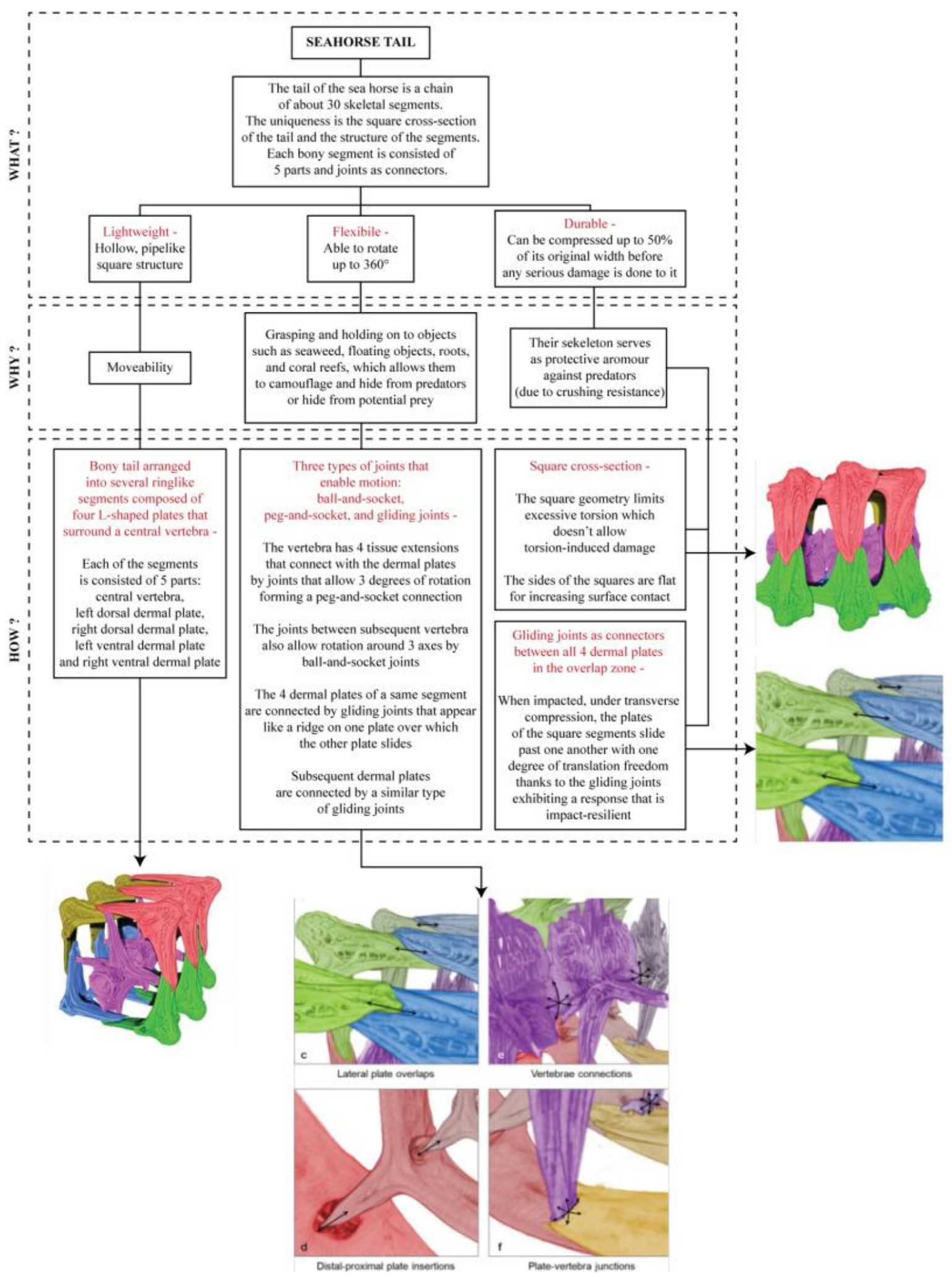

Figure 2. Functional decomposition (Source of used images: Justin Holt, Design and Testing of a Biomimetic Pneumatic Actuated Seahorse Tail Inspired Robot [13])

The principles define a structure that can be applied to design products that need to be durable and that are under the influence of load. The key feature is the amortization of weight forces with preserved flexibility. The appearance and functionality of the natural phenomenon open up a new way of thinking in the field of design and engineering. So far, these types of structures and similar ones have been used in robotics [6]. However, the great properties of this small and compact system with ideally fitted parts and joints can be applied in commercial products where there is a need to reduce the weight while moving freely.

\section{IDENTIFICATION OF A PROBLEM TO BE SOLVED}

While searching for products with the needed characteristics, a problem was noticed in the design of school backpacks. The main purpose of a backpack is a 
successful transportation of books and school equipment while distributing the weight evenly in order to achieve best ergonomic properties, and support the posture of the children. However, poor design of backpacks and overloading them causes increased pressure in the neck and upper and lower back of the children resulting with serious spine deformities.

For decades, scoliosis, kyphosis and lordosis have been most commonly detected in student's medical examinations (Fig. 3). Latest statistics from student's medical examinations published by the Institute of Public Health in Skopje show that spine deformities, poor body posture and poor nutrition are the top most common pathological conditions identified during the medical examinations of primary school and high school students [14].

\subsection{Deformities of primary school students}

The statistics from students medical examinations from the year 2017/18 show that spine and chest deformities have been noted in $25.4 \%$ of the total examined students, $14 \%$ of the students had bad body posture and foot deformities were found in $13.8 \%$ of the examined students (Fig.4).

\subsection{Deformities of high school students}

From the total number of examined high school students in the year 2017/18, 25.2\% had a bad body posture, $20.4 \%$ had back and chest deformities and $11.2 \%$ had foot deformities (Fig. 5).

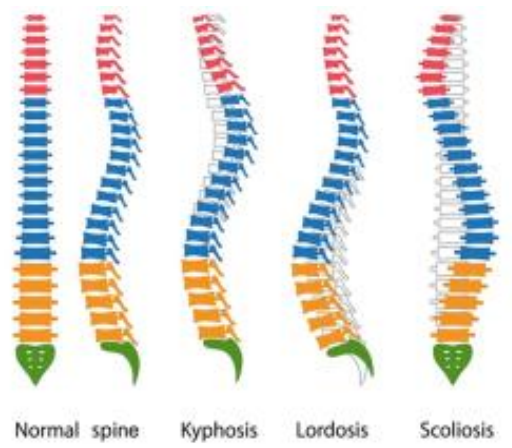

Figure 3. Different types of spine deformities (Source: news-medical.net)

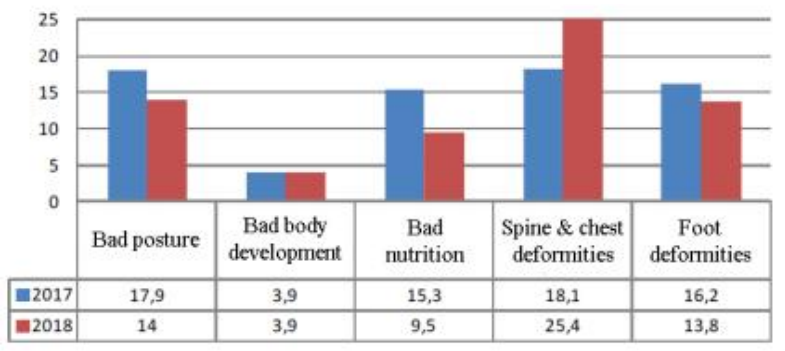

Figure 4. Most common pathological conditions identified in medical examinations of primary school students (Source: Institute of Public Health in Skopje [14])

These conditions have a chronic and lifelong nature and their most common causes are: absence of physical activity, multiple hours of improper sitting. Another reason is the weight of school backpacks that is unevenly distributed on the back and shoulders of the chil- dren due to design flaws - backpacks that are not ergonomic and cause improper body posture. Moreover, these backpacks are usually loaded more than allowed, with a weight of $10-22 \%$ of the body weight of the children. An Infographic by Jan Diehm for The Huffington Post [15] illustrates what heavy backpacks can do to the child and the type of backpacks that should be used (Fig. 6).

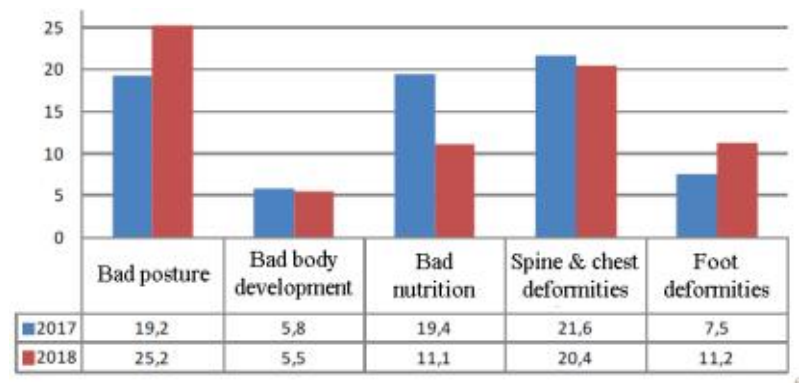

Figure 5. Most common pathological conditions identified in medical examinations of high school students (Source: Institute of Public Health in Skopje [14])

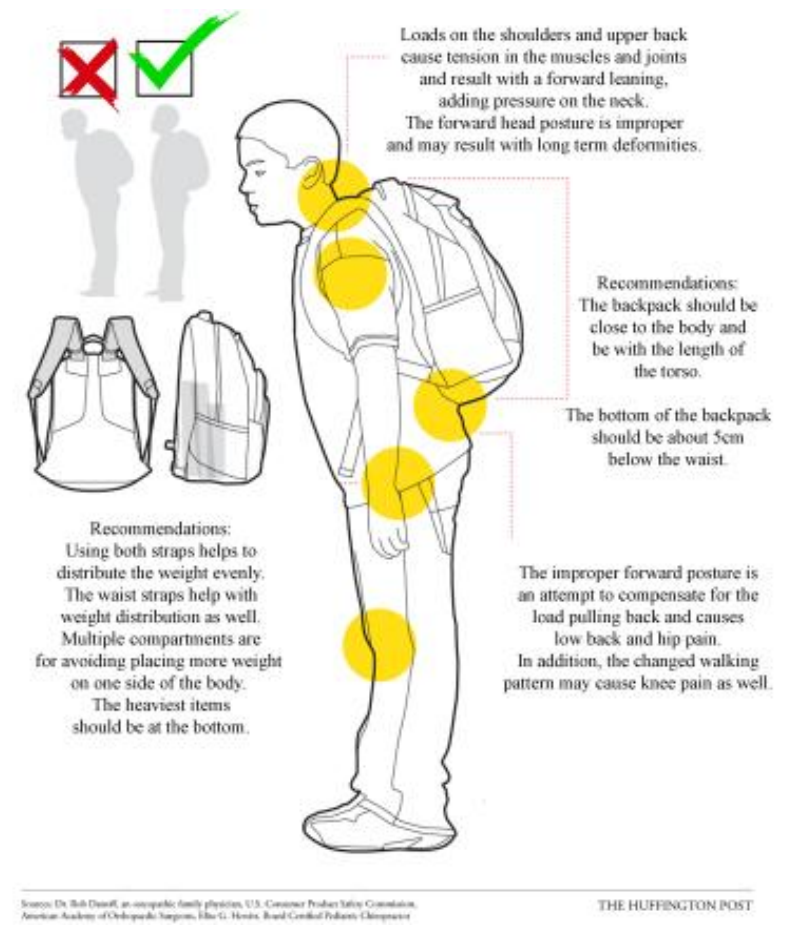

Figure 6. Influence of backpacks on the back and posture of children (Adapted from Jan Diehm, Source: huffpost.com)

Therefore, it is crucial to use school backpacks specifically designed to suit the student's daily activities, improve their posture and help promote their healthy development, rather than be the main cause of deformities.

The main requirements a properly designed school backpack should meet are:

- Carrying load on the back without causing shoulder and back pain

- Durable material

- Shape that doesn't deform the contents

- Several compartments for an even distribution of the weight

- Colours and textures appealing to children

- Dimensions defined by following the anthropometric measurements of children 
- Shape that helps maintain a good posture

- Wide and soft straps that reduce the pressure of the load

- Adjustable dimension of the straps

- Two additional straps in the chest and waist area for better support

Taking all this into consideration, it is important to emphasise that the primary design principles that need to be followed when creating school backpacks are ergonomics. Proper support for the back and shoulders that would ease the load and allow a good posture and movement would reduce the problem with a high percentage of children with back and chest deformities.

The seahorse skeleton and its properties are a direct inspiration for creating a support system that can be included inside school backpacks and that would help achieve maximal ergonomics.

\section{DESIGN OF A SCHOOL BACKPACK BASED ON THE SEAHORSE SKELETON PROPERTIES}

The basic idea that emerged from the analysis of the natural phenomenon and the problem that needs to be solved is to simplify the skeletal structure of the seahorse to a basic mechanical system that will still have the same features as the biological system - the durability while compressed by heavy loads while remaining lightweight and flexible. The designed mechanical system would be included in the design of school backpacks. The idea is for the system to act as a weight supporter and load-force damper. It would be embedded in the backpack straps and the specially designed back pad that is in contact with the back of the child. The system itself would be inserted beneath the materials so that it would not be visible and would not disrupt the design of the exterior, but would still perform its function successfully. With this type of design a significant increase in ergonomic features is foreseen, thereby increasing comfort and reducing pain and pressure in the back and shoulder area when wearing a backpack.

\subsection{Design - functional analysis}

The 3D models that follow show the way the support mechanism is designed - as a chain of square segments (Fig. 7) each containing 4 springs for damping of loadforces that are connected with the sides and the core by "ball-and-socket" joints that allow free movement (Fig.8). The segments are also connected with each other by springs attached to their central parts with the same type of joint systems (Fig. 9). This structure imitates the seahorse's skeleton, it is lightweight and enables an even distribution of forces meaning that their impact would be reduced.

The functionality of the designed system is explained in greater depth on the following image (Fig. 10). The illustration of the functional analysis is done in the same manner the functional decomposition of the natural phenomenon was made. This reveals the used method for extracting and applying the defined natural characteristics. The image explains the characteristics of the designed product (What?), the purpose those func- tions serve (Why?) and the way those functions are achieved in order to serve the defined purpose (How?).

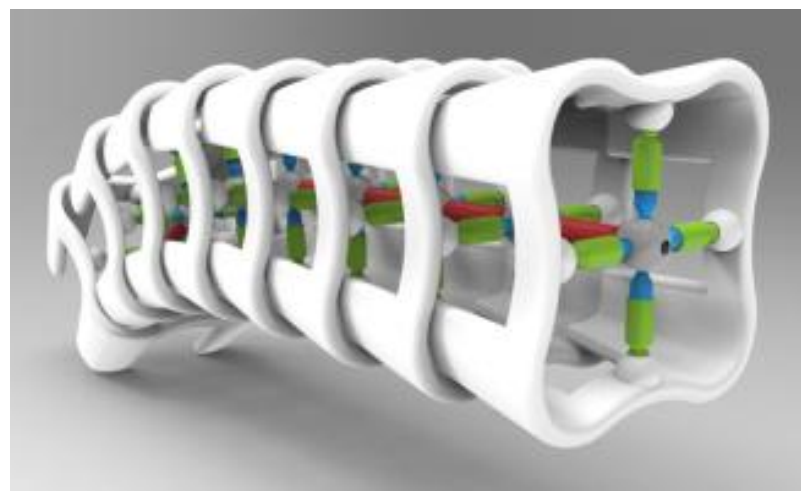

Figure 7. 3D model of the designed support mechanism consisted of a chain of segments with springs attached to the sides and a centre with 'ball-and-socket' joints

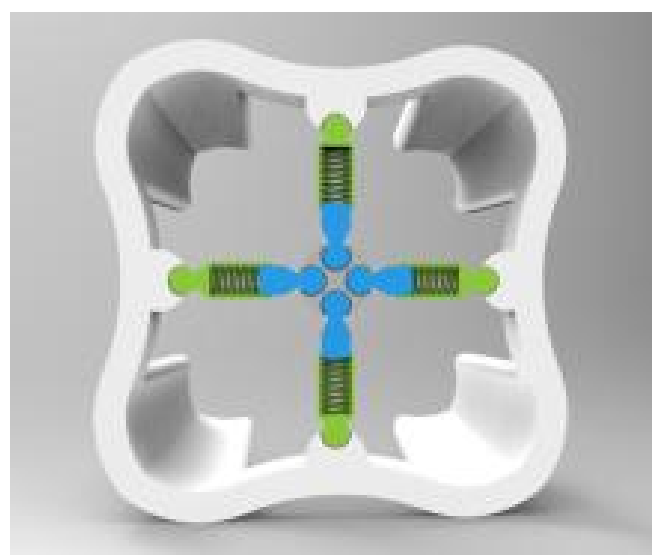

Figure 8. Section view of the springs and joints of one segment

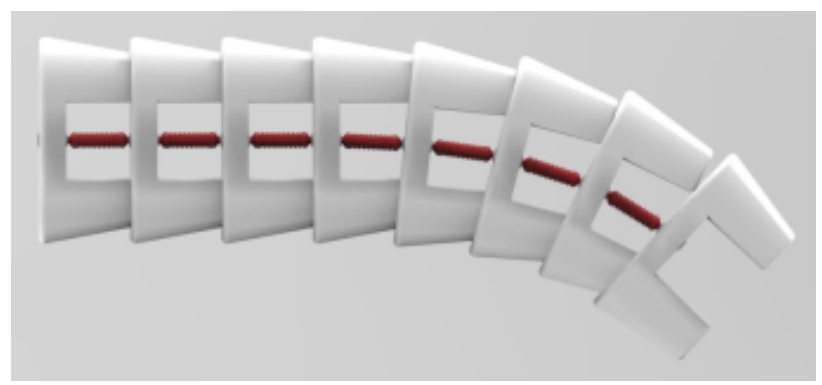

Figure 9. Subsequent segments of the mechanism connected by springs

The overall design of the backpack is ergonomic, with wide shoulder straps, additional straps in the chest and waist area, multiple departments for an even distribution of the weight, and a back pad with a shape following the natural curvature of the spine and supporting an upright posture (Fig.11).

The created mechanism is to be inserted inside the shoulder straps and the back pad in order to provide maximal absorption of the load forces while carrying the backpack (Fig. 12). The mechanism does not influence the appearance of the backpack since it is not visible. Therefore, the design can be both extremely ergonomic and modern and appealing. The possibilities for combining different textures and colors to meet the needs of the target group are endless (Fig. 13). 


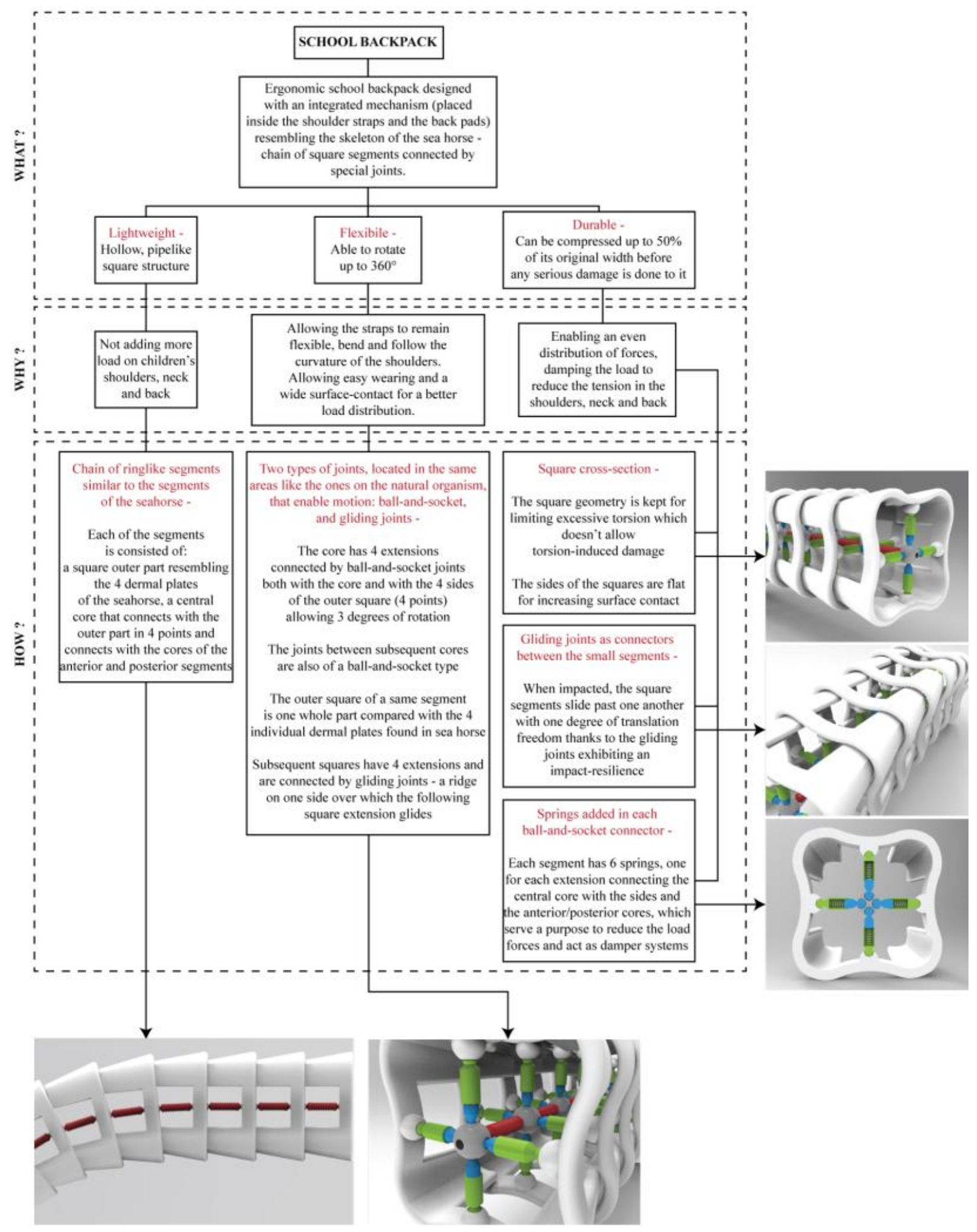

Figure 10. Functional analysis of the designed mechanism for school backpacks

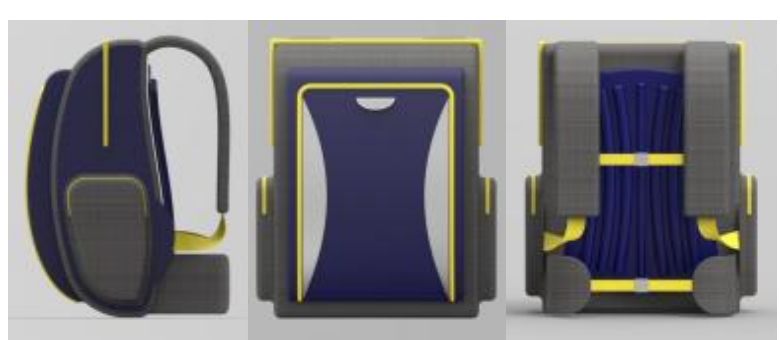

Figure 11. 3D model of the whole ergonomic backpack

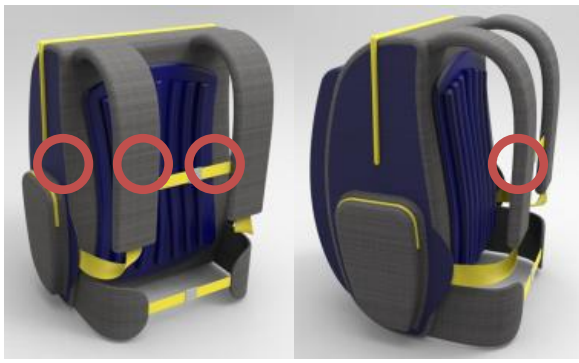

Figure 12. Placement of the mechanism inside the shoulder straps and back pad 

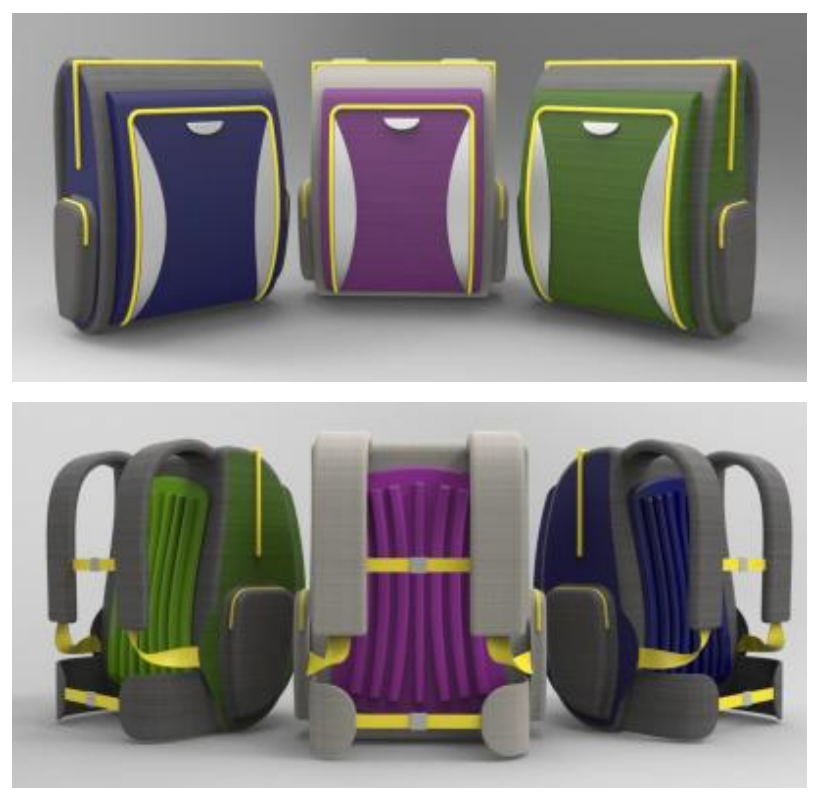

Figure 13. 3D models of the backpack showing a variety of colour combinations

\subsection{Anthropometric measurements}

When defining the size of a school backpack, two basic dimensions are crucial: the distance between the straps, and the width and length of the backrest. After defining the average age of the students for which the backpack is designed, in order to achieve maximum ergonomics and a balanced weight distribution, it is important to determine the average distance between the shoulder line and the waist line and the average distance between the shoulders. The length of the backrest is defined by the average distance between the shoulder line and the waist line plus $5 \mathrm{~cm}$, while the distance between the straps is defined by the average distance between the ridges of the shoulder blades (Fig. 14). It is important to have additional straps around the waist for support because that will help distribute some of the weight of the backpack to the hips rather than just to the back and shoulders.

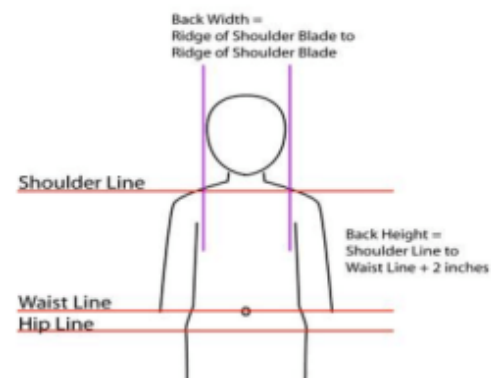

Figure 14. Fitting guide for a backpack (Source: Farideh Babakhani, The effect of backpack load on the posture of children [16])

When designing this school backpack, the target group considered were pupils aged $12-15$ years. Following a size chart for defining the dimensions of the backpack that should not be larger than the back of the children that would be carrying it [16], the backrest length was defined to be $482 \mathrm{~mm}$, the distance between the center of the straps was defined to be $229 \mathrm{~mm}$, while the maximum width of the entire backrest was defined to be $349 \mathrm{~mm}$ (Fig. 15).

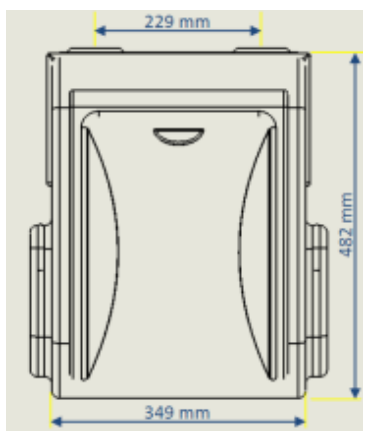

Figure 15. Basic dimensions of the designed backpack

\section{DISCUSSION}

Basing design and engineering solutions on biological principles is an approach that results with successful products that solve existing problems and meet specific functional requirements. Therefore, it is necessary to constantly search for unique biological systems and think of ways their functionality can be applied in everyday items.

Noticing the characteristic skeletal structure of the seahorse, its load-bearing properties with retained flexibility, was an inspiration to explore fields where these features would be important for improving the practical properties.

Noticing the problem of frequent spine deformities in primary and high school students and analyzing the causes for these medical conditions defined the flow of the reformulation of the biological solution. This resulted with the idea for designing a school backpack with improved ergonomic properties - a backpack with an integrated mechanical system based on the biological skeletal structure of the seahorse.

The final result was a design of a school backpack that would respond to the need to achieve maximum ergonomics. Firstly, it has appropriately applied anthropometric measurements, with a defined shape that should help the body be constantly upright and the posture to be correct. Secondly, it has wide, soft and flexible shoulder straps and extra straps in the chest and waist area for better support. Finally, it should provide an even distribution of weight and damping of the load forces, thus reducing the muscle tension and back pain, thanks to the bionic mechanisms inserted in the shoulder straps and back pad.

For best evaluation and improvement of the properties of the mechanisms, the software model should be used in combination with a $3 \mathrm{D}$ printer to create real models of the mechanisms, insert them into a sewn model of the designed backpack and perform experiments with a focus group consisted of children aged $12-15$. Measuring the load forces and the tension they create on the shoulders, neck and back of the children would show exactly how beneficial this idea is. This remains a suggestion for further research on this subject.

\section{CONCLUSIONS}

The design of a back-support system for backpacks inspired by the seahorse skeleton is one more example of how a structured bionic approach can be used in the 
design process. The "top-down" and "bottom-up" methods combined with the adequate reformulation of the properties of the identified natural phenomena (What?, Why?, How?), or identified problem that needs to be solved, are very useful for a better systematization of ideas, and should therefore be used in the educational process. This approach can stimulate the creative thinking among design and engineering students, help them expand their knowledge and come up with ingenious ways to apply unique functional and aesthetic properties recognized in nature in the development of new products.

\section{REFERENCES}

[1] Versos, C. A. M., Coelho, D.: Biologically Inspired Design: Methods and Validation, in: Industrial Design - New Frontiers, IntechOpen, pp. 101 - 120, 2011.Gross, A. W.: Gas film lubrication, John Wiley and Sons, New York, 1992.

[2] Salgueiredo, C. F.: Modeling inspiration for innovative NPD: lessons from biomimetics, in: 20th International Product Development Management Conference, Jun 2013, Paris, France, pp.21.

[3] Helms, M., Vattam, S. S., Goel, A. K.: Biologically inspired design: process and products, Design Studies, Vol. 30, No. 5, pp. 606 - 622, 2009.

[4] Versos, C. A. M., Coelho, D. A.: A Bi-directional Method for Bionic Design with Examples, in: Advances in Industrial Design Engineering, IntechOpen, (doi: 10.5772/53417), 2013.

[5] Gavrilović, N., Rašuo, B., Dulikravich, G., Parezanović, V.: Commercial aircraft performance improvement using winglets, FME Transactions, Vol. 43, No. 1, pp. 1-8, 2015.

[6] Stevanović, I., Rašuo, B.: Development of a Miniature Robot Based on Experience Inspired by Nature, FME Transactions, Vol. 45, No. 1, pp. 189197, 2017.

[7] Neurohr, R., Dragomirescu C.: Bionics in Engineering - Defining new Goals in Engineering Education at "Politehnica" University of Bucharest, in: International Conference on Engineering Education, September 3 - 7 2007, Coimbra, Portugal.

[8] Sidorenko, S.: Improvement of creativity via the six-step bio-inspiration strategy, in: South East European Journal of Architecture and Design, Vol. 2017, pp. 1-8, 2017, https://doi.org/10.3889/seejad .2017 .10028

[9] Zdravkova A., Mircheski I., Sidorenko S., BioInspired Approach for Innovative Design of Knee Protectors for Recreational Sports, in: $F M E$ Transactions, Vol. 48, No. 4, pp. 849-854, 2020.

[10] Gerasimovski, N., Angeleska, E., Sidorenko, S.: Bionic principles of space optimization applied in the product design process, in: $M E S J$, Vol. 37, No. 1, pp. 107-115, 2019.
[11]Emami, J., Tashakori, M., Tashakorinia, Z.: Bionic Design in Industrial Design Education at University of Tehran, in: Proceedings of E\&PDE, International Conference on Engineering and Product Design Education, September 04 - 05 2008, Barcelona, Spain.

[12] Praet, T.: The Biomechanical Structure of the Sea horse Tail as a Source of Inspiration for Industrial Design, PhD Thesis, Ghent University, Faculty of Engineering and Architecture, Ghent, Belgium, 2013.

[13]Holt, J.: Design and Testing of a Biomimetic Pneumatic Actuated Seahorse Tail Inspired Robot, MSc Thesis, Graduate School of Clemson University, in: Tiger Prints, All Theses, 2637, 2017.

[14]Public Health Institute Skopje: Report on the Realization of the Program for Systematic Medical Examinations of students in the Republic of Macedonia 2017 - 2018, in: CIP - National and University Library St. Kliment Ohridski, Skopje, 616-07-057.87 (497.7)»2017/2018» (047), 2018.

[15] Samakow, J.: The Dangers of Heavy Backpacks And How Kids Can Wear Them Safely, in: Huff Post, https://www.huffpost.com, 2017.

[16] Babakhani, F.: The effect of backpack load on the posture of children and its relationship to trunk muscle activity during walking on a treadmill, Dissertation submitted to the faculty of the social and applied human sciences at Saarland University, 2011.

\section{БИО-ИНСПИРИСАН СИСТЕМ ЗА ПОДРШКУ ЛЕЪИМА ЗА РАНЧЕВЕ}

\section{Е. Ангелеска, С. Сидоренко}

Рад приказује бионички приступ изналажења решења у процесу редизајна производа ради унапређења његових ергономских својстава. Постављени циљ је преформулисање и коришћење својстава јединственог природног феномена у специфичној области дизајна. Структура скелета морског коњица, капацитет носивости са продуженом флексибилношћу представљали су подстицај за истраживање производа код којих би се ова својства могла применити у циљу унапређења функционалности. Истраживање је резултирало откривањем проблема који настаје услед лошег дизајна производа - проблем деформације кичме код ученика изазван неергономским школским ранчевима. Тако смо дошли на идеју да применимо анализирана биолошка својства у дизајнирању школских ранчева са побољшаном ергономијом. Добили смо ранчеве са интегрисаним механичким системом базираним на биолошкој структури скелета морског коњица, чиме се постиже максимални комфор и подршка правилном држању ученика. 